\title{
Credit Evaluation by the Small-Medium Sized Enterprises: Maqasid Shariah Approach
}

\author{
Mustafa Al-Malhuki Abdul Aziz, Siti Zaleha Abdul Rasid, Nadiah Aziz
}

To Link this Article: http://dx.doi.org/10.6007/IJARBSS/v11-i10/10919 DOI:10.6007/IJARBSS/v11-i10/10919

Received: 04 August 2021, Revised: 28 August 2021, Accepted: 20 September 2021

Published Online: 03 October 2021

In-Text Citation: (Aziz et al., 2021)

To Cite this Article: Aziz, M. A.-M. A., Rasid, S. Z. A., \& Aziz, N. (2021). Credit Evaluation by the Small-Medium Sized Enterprises: Maqasid Shariah Approach. International Journal of Academic Research in Business and Social Sciences, 11(10), 190-204.

Copyright: @ 2021 The Author(s)

Published by Human Resource Management Academic Research Society (www.hrmars.com)

This article is published under the Creative Commons Attribution (CC BY 4.0) license. Anyone may reproduce, distribute, translate and create derivative works of this article (for both commercial and non-commercial purposes), subject to full attribution to the original publication and authors. The full terms of this license may be seen at: http://creativecommons.org/licences/by/4.0/legalcode

Vol. 11, No. 10, 2021, Pg. 190 - 204

Full Terms \& Conditions of access and use can be found at http://hrmars.com/index.php/pages/detail/publication-ethics 


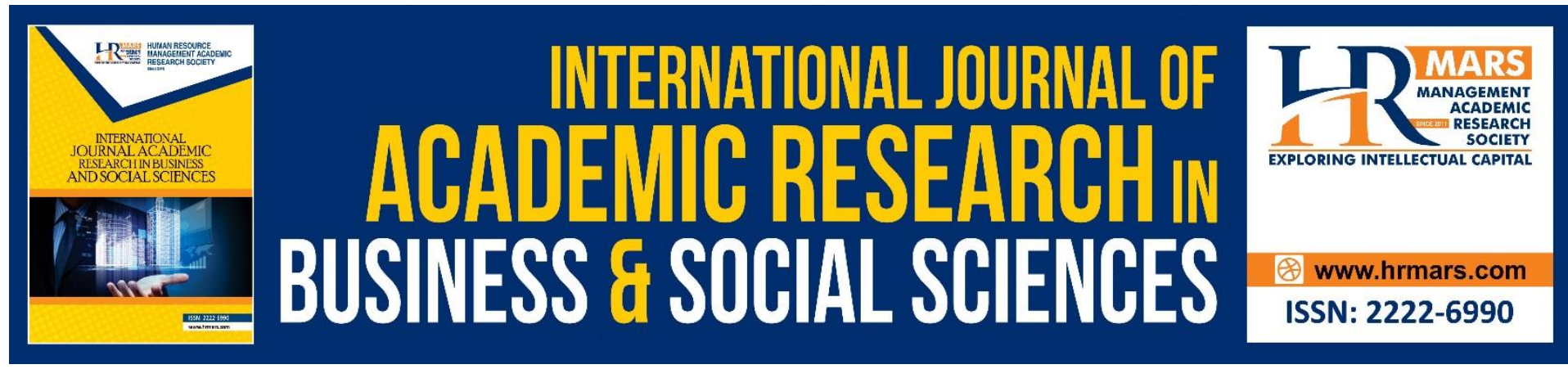

\title{
Credit Evaluation by the Small-Medium Sized Enterprises: Maqasid Shariah Approach
}

\section{Mustafa Al-Malhuki Abdul Aziz¹, Siti Zaleha Abdul Rasid', Nadiah $\mathrm{Aziz}^{2}$}

${ }^{1}$ Azman Hashim International Business School, Universiti Teknologi Malaysia (UTM), Jalan Sultan Yahya Petra, Kampung Datuk Keramat, 54100 Kuala Lumpur, Malaysia, ${ }^{2}$ Faculty of Communication and Creative Industries, Tunku Abdul Rahman University College, Jalan

Genting Kelang, Setapak, 53300 Kuala Lumpur, Malaysia

Email: mustafa_almalhuki@yahoo.com,szaleha.kl@utm.my,nadiahaa@tarc.edu.my

\begin{abstract}
This paper aims to examine the practice of credit evaluation by Islamic banking in evaluating financing proposals from the SMEs in Malaysia. Also, how the approach of Maqasid Shariah which encompasses of religion, life, lineage, intellect and property influencing the application of credit evaluation from the SMEs. This paper measures credit evaluation on Islamic banks based on review of literature; the inputs are extracted from the existing relevant studies on the subject matter. The findings reveal that that the elements of Maqasid Shariah are not being considered meticulously for credit evaluation processes. The Maqasid Shariah approach in credit evaluation could bring significant values for SMEs in securing financing. This novel study significantly focuses on how the SMEs in Malaysia process the credit evaluation based on the CAMPARI model while adapting the concept of Maqasid Shariah. As this conceptual paper focuses on the previous research and existing available data, the paper is a steppingstone that enables the researchers to obtain an inclusive and complete perspective and solutions for both Islamic banking system and their customers.
\end{abstract}

Keywords: Islamic Banking, Credit Evaluation, Maqasid Shariah, CAMPARI, Small-Medium Sized Enterprise

\section{Introduction}

The credit processes are imposed for banks to ascertain lending decisions on financing applications. Each bank has its unique credit process and procedures, which typically depends on the quantum of the applied amount type of banking facilities. For retail segments such as credit card, mortgage and hire purchase, lending decision processes typically are more relaxed which do not require loan committee approval, unlike the business segment where financing decisions require loan committee approval. Credit processes require banks to use certain credit evaluation tools to understand and assess the applicants' credit standing. One of the prominent credit evaluation tools is CAMPARI Model where 7 elements are being evaluated to understand the credit strength. CAMPARI (Character, Ability, Margin of Financing, Purpose, Amount, Repayment and Insurance) is an old model used in the banking 
industry to define good/bad credit for business loans. Although banks call their credit evaluation methodology in various names, it is actually anchoreded in these similar fundamental element that focus on customers' credit-standing and availability of recourse.

In the lenses of Islamic banking, Islamic banking is well known as ethical banking or high moral banking (Mohamad, Basah, and Aziz, 2018), which supposedly to be more proactive in empowering business through financing. Islamic banks are expected to uphold Islamic rulings (Shariah) in their business framework and principles, in which Maqasid Shariah promotes social justice to the mankind and other creations (Oladapo and Ab Rahman, 2016). Therefore, Islamic banking is expected to analyze businesses' financing applications in different standards as compared to conventional banking. Islamic banking shall analyze the financing application by embracing Shariah considerations. Mohamad et al (2018) further argue that Islamic banking's behaviors toward these seven aspects may differ from conventional banking, given its spirit of risk-sharing and its approach based on Maqasid Shariah, compared to conventional banking.

Islamic rulings i.e. Shariah is guiding Islamic banking. The objective of Shariah is divided into three levels of necessity which are Necessities (Dharuriyat), Needs (Hajiyat) and Luxuries (Tahsiniyat). However, the most crucial Maqasid Shariah is Necessities where it is crucial for the human being, such as food, shelter, and cloths. Under the Necessities category, there are five shariah objectives: Protection of Religion, Protection of Life, Protection of Lineage, Protection of Intellect and Protection of Property. Being Islamic banks, these five preservations should be upheld in evaluating businesses' financing applications.

SME clientele is the most important segment due to its core function in the national economy, and it is no doubt that SMEs play vital roles in Malaysia's economic development. One of the main issues concern the most for SMEs is accessibility to financing. Unlike large corporations, SMEs' reliance on external financing is crucial due to the tight weak financial standing resulting from small-scale business operations. Jamil, Zakaria and Othman (2019) believed that SMEs are using owners' personal loans and credit cards to fund their businesses, which is a mismatch funding. Mismatched funding could affect SMEs' business performance as a study conducted by Mustafa, Sam and Ismail (2019) revealed a positive relationship between facility structure and SMEs' performance. There are many reasons why SMEs are facing difficulties in securing fundings, one of which is lack of collateral, as suggested by Wasiuzzaman, Nurdin, Abdullah and Vinayan (2020), Haron, Said, Jayaraman and Ismail (2013) and Zairani and Zaimah (2013).

Overall, the findings of this study shall bring contributions to the present research on SME financings which to understand the key determinants for an Islamic bank to make a lending decision on SMEs in Malaysia in the perspective of Maqasid Shariah. This study is very important for SMEs and Islamic banks, especially in determining the fallbacks and the opportunities that both can leverage.

\section{Review of the Literature}

The most recent study on credit evaluation in Maqasid Shariah perspective was conducted by Mohamad et al. (2018). This research was conducted to understand the credit evaluation process based on Islamic values of Adl, Ukhwah, Istiqomah, Akhlak, Syura and Tawakkal, as 
well as elements of Maqasid Shariah which are Daruriyyah, Hajiyyah and Tahsiniyyah. The study had two main objectives, which are (i) exploring Islamic elements that can be used in evaluating commercial financing application in Islamic banking and (ii) proposing the best parameter for the credit evaluation process in commercial financing. However, the said study focused only on broad elements of Maqasid Shariah, as the study only interested in ascertaining which elements in Maqasid Shariah are important in making a financing decision. In addition, the study did not consider the components of each element in the credit evaluation process. Furthermore, the respondents of the study was Shariah Advisors, who probably have limited exposure to credit discipline. Lastly, the study focused on general credit evaluation, which applies to all applicants regardless of their company size and capacity. Therefore the result may be deemed inconclusive as one size cannot fit all.

\section{Credit Evaluation Tools}

Financial institutions are using many models in evaluating loan and financing applications. Although each bank has its respective evaluation methodology, Zairani and Zaimah (2013) highlighted that financial institutions use almost similar evaluation methods where the key considerations are the same. Some models focus on the applicants' credit history, where the pattern of repayment and late payment history will be considered. Some lenders consider liquidity as the core supporting element as it is deemed to ascertain applicants' ability to pay during financial distress. The most common criteria for the evaluation are the availability of securities, especially for SMEs. In Malaysia, lenders tend to request securities for SMEs financing, which is deemed difficult to them, resulting in SMEs eventually access to credit through personal loans and credit cards (Jamil et al., 2019).

Credit evaluation requires detailed works based on a particular model developed by respective financial institutions. The credit appraiser must be furnished with sufficient data and typically the appraisers heavily rely on external data (Purohit et al., 2012). Three famous credit evaluation tools are widely being used by lenders namely $5 \mathrm{Cs}$, 7Cs and CAMPARI Model. The 5Cs model is an acronym for Character, Capacity, Collateral, Capital and Condition, which is used by lenders to analyze the credit standing of the customer and to understand their customers better (Moti, Masinde, Mugenda and Sindani, 2012). The Character is an individual impression of the applicant that translated into perception by the lender (Myers and Forgy, 2015). While Capacity is defined as applicant's ability to repay the financial obligations through its cashflow (Bhatt, 2012). Collateral is assets being pledged to the lender as a settlement consideration in case the customer defaults. Bhatt (2012) highlighted that Capital is the money invested by the shareholders for the business, while Condition is the surrounding environment that could affect the business, such as industry and economic outlook.

The 7Cs is an enhancement model of 5Cs which have various models. MacDonald and Timith (2006) added that the additional two Cs are Control (ability to manage and control the business) and Common Sense (ability of the applicant to make good decision). Metzler (2014) highlighted that the additional two Cs are Credit (credit history) and Commitment (commitment of owner to succeed in the business). While CAMPARI Model is another famous credit evaluation model which an acronym for Character, Ability, Margin of Financing, Purpose, Amount, Repayment and Insurance. 
Hassan (2020) suggested that 5Cs and CAMPARI are the most famous evaluation model being used, while the other evaluation models have similar elements with these two models. Mohamad et al. (2018) conducted a study comparing two famous models, i.e. 5Cs and CAMPARI, which revealed that Full-fledge Islamic banks tend to use CAMPARI evaluation model as compared to $5 \mathrm{Cs}$ due to the existence of elements of ability to pay, character and amount. The study also suggested that the element of purpose in the CAMPARI is crucial for evaluation as the lenders need to ascertain the applicants' intention. W/Mariam (2017) believed that the elements in the CAMPARI are relevant for lending decisions, especially elements of character, ability to pay, purpose and amount. Abbadi and Karsh (2013) conducted a statistical analysis on five evaluation models, namely 5Cs. LAPP, 5Ps, CAMPARI and FAPE resulted in CAMPARI scoring the highest average in terms of the most important elements in the credit evaluation. Therefore, recent studies conclusively revealed that CAMPARI model is the most relevant credit evaluation for lending decision making.

In this study, CAMPARI Model is chosen as the subject matter of study for the credit evaluation model. The elements in CAMPARI are fundamentally similar to $5 \mathrm{Cs}$ and $7 \mathrm{Cs}$, although the given names are different.

\section{CAMPARI Model and its Elements}

CAMPARI is meant to evaluate borrowers' creditworthiness and ascertain the strength of a proposal, including remedy measures should the borrower not meet its financial obligations. The application of CAMPARI to the credit process is expected to reduce overall nonperforming financing (Kithinji, 2010).

The first element of CAMPARI is character which Abbadi and Karsh (2013) defined as borrower's sense of obligation towards repayment commitment, which means borrower's seriousness or attitude toward financial commitment defines borrower's actual characters. This repayment attitude can beobserved via repayment record from previous/existing loans with other financial institutions and conduct of operating bank account (W/Mariam, 2017). In other words, character is defined as integrity and honesty of the company and its management (Brown and Moles, 2014). Second element is the ability to repay which can be ascertained bi assessing the customer's cash adequacy for paying principal and profit repayments as well as the new proposed debt (Association of Banks in Malaysia, n.d.). While margin of financing is defined as percentage of advance imposed by the banks (Association of Banks in Malaysia, n.d.). For example, if the Margin of Finance is $80 \%$ for loan of RM10 million, the borrower is expected to advance RM2 million prior to bank's disbursement of RM8 million. While purpose of financing as the fourth element in CAMPARI is a crucial element as highlighted by Abadi and Karsh (2013) that the purpose of financing must be clearly justified and explained how the financing proceed will be utilized. Recognition of the risk related to a particular financing starts with identification of financing purpose as the credit officer should understand the exposure that the bank is taking. Amount is the fifth element of CAMPARI which the assessment done to know if the applied amount is reasonable sufficient to fund the purpose of financing (Brown and Moles, 2014). The asking amount must be reasonable as compared to the customer's capacity and actual cost of project/asset of the intended financing purpose as the loan amount is a controlling measure to minimize the potential risk (Jamil et al., 2019).The sixth element is repayment which consist of assessment on the terms and amount of repayment to be paid by the customer (Association of Banks in Malaysia, n.d.). The repayment structure varies depending on the cashflow of the borrower, subject to 
lender's approval. Typically, repayment structure influents credit scoring in a bank as part of balancing customer behavioral risk (Wasiuzzaman and Nurdin, 2019). The last element of CAMPARI is insurance, also known as security, which is a mechanism to secure lender's position in case the borrower fails to meet the financial obligations (Brown and Moles, 2014). The value of the available securities can significantly affect the lending decision, especially if the securities are legally owned by the borrower, which is easy for lenders to monetize the securities for repayment purpose (Siswanto, Arifin and Cavin, 2019).

\section{Five Principles of Maqasid Shariah}

Maqasid Shariah is derived from two words: Maqasid and Shariah, which means objective and Islamic divine law respectively, thus the words self-explanatorily the theory on the objectives of Islamic divine law (Oladapo and Ab Rahman, 2016). Various scholars developed the concept of Maqasad Shariah. However, Abu Hamid al-Ghazali, also famously known as Imam alGhazali, (n.d.) developed further his teacher's theory and ordered the necessities into these five elements as mentioned above. His concept was approved by many scholars, including Imam Al-Shatibi (Dusuki and Abozaid, 2007). Imam al-Ghazali developed the concept of Maqasih Shariah in the 12th Century in his book named Al-Mustasfa Min 'Ilm al-Usul (On Legal theory of Muslim Jurisprudence).

In relation to Islamic banking's lending practices, this research shall discuss Maqasid Shariah in the context of Necessities (Daruriyyah) which is more related to the underlying issues. The other two pillars of Maqasid Shariah, which are Hajiyyat (needs) and Tahsiniyyat (embellishment), are not much related to SME financings because financing is deemed a necessity for SMEs for their growth and business continuation. Borrowing and external financing is only sought by a person or a company in desperate situation to support their current financial situation. Furthermore, Daruriyyah is the fundamental to Hajiyyah, while Hajiyyah is the fundamental to Tahsiniyyah. In other words, Daruriyyah is the most fundamental element in Maqasid Shariah as it protects the welfare of the lives in the earth. Therefore, the research will evaluate Islamic banking's practice in the lenses of preservation of five elements in Daruriyyah i.e. faith, soul, intellect, offspring and wealth.

\section{Protecting Faith}

Protecting faith/religion is the core of shariah where Muslims are demanded to defend anything that might violate or destroy fundamental of Islamic ruling. Example of protecting faith is avoiding giving funding to any business that may lead to shirk or fundamentally wrong to Islam such as black magic business. Protecting faith is very important as Aqidah is the backbone of religion. In surah Ali' Imran, verse 19 Allah says, "Indeed, the religion in the sight of Allah is Islam. And those who were given the Scripture did not differ except after knowledge had come to them - out of jealous animosity between themselves. And whoever disbelieves in the verses of Allah, then indeed, Allah is swift in [taking] account." In the same surah Ali' Imran, in verse 85 Allah says, "And whoever desires other than Islam as religion - never will it be accepted from him, and he, in the Hereafter, will be among the losers."

\section{Protecting Soul}

In Islam, one's life is valuable, and a mankind has no right to take or harm others' live. Allah says in Surah Al An'am, verse 151 "...And do not kill the soul which Allah has forbidden [to be killed] except by [legal] right. This has He instructed you that you may use reason.". Besides 
lives need to be protected, scholars also agreed that soul is not limited to life alone, but also covers a wider scope of life including protecting one's honor, brotherhood, dignity and safety. Besides that, level of poverty and preserving harmony are included in the scope of soul preservation in Maqasid Shariah. This consistent with Allah's revelation in Surah Al Baqarah, verse 178 "O you who have believed, prescribed for you is legal retribution for those murdered - the free for the free, the slave for the slave, and the female for the female. But whoever overlooks from his brother anything, then there should be a suitable follow-up and payment to him with good conduct. This is an alleviation from your Lord and a mercy. But whoever transgresses after that will have a painful punishment.". In the context of banking, an example of protecting soul can be describe as fairness and integrity in granting banking facility to SMEs for accommodating fair wealth distribution as well as narrowing income gap among the society.

\section{Protecting Intellect}

Intellect or mind is the most important asset of our body as it has direct affect to our attitude and behavior, which intellect is the key differentiation between human and other creations. Islam encourages human beings to preserve the quality of intellect by avoiding any harmful intake to the body such as alcoholic drinks and drugs that will disable human capacity to think and act rationally. This ruling mentioned by Allah in Surah Al-Ma'idah, verse 90 "O you who have believed, indeed, intoxicants, gambling, [sacrificing on] stone alters [to other than Allah], and divining arrows are but defilement from the work of Satan, so avoid it that you may be successful." Therefore, Islamic banking should uphold this concept by not granting any banking facility to any business that associated to gambling and unauthorized/unlawful drugs.

\section{Protecting Offspring}

Marriage is legitimized in Islam for the purpose to protect lineage and offspring (nasabah). Adultery is a sinful action in Islam and there are specific punishments within shariah ruling for those committed adultery. Allah warns mankind on adultery in Al-Quran as state in Surah AlIsra, verse 32 Allah says "And do not approach unlawful sexual intercourse. Indeed, it is ever an immorality and is evil as a way. ". Protecting offspring and lineage is also important in Islam as the Muslim must preserve aurat (body parts need to be covered according to Islam) as well as heritage wills. In Islamic banking and finance discipline, heritage wills are the key consideration in granting banking facility.

\section{Protecting Wealth}

Islam encourages mankind to pursue wealth in this world as long as the wealth is permissible, being justice to others and not excessive in the expense of forgetting Allah. There is no limit in Islam how much a person should be collecting wealth, however any action of gathering wealth must always within shariah principles and should not harm others in the future. Protecting wealth is not only limited to one self's wealth, but also protecting society's wealth from harm including stealth, interest, corruption, bribery and unfair monopoly. Various verses in Al-Quran emphasizes on this final preservation. Allah says in Surah al-Baqarah verse 188 "And do not consume one another's wealth unjustly or send it [in bribery] to the rulers in order that [they might aid] you [to] consume a portion of the wealth of the people in sin, while you know [it is unlawful]". In other verse, Allah warns mankind from taking orphans' wealth as mentioned in Surah An-Nisa, verse 2 "And give to the orphans their properties and do not 
substitute the defective [of your own] for the good [of theirs]. And do not consume their properties into your own. Indeed, that is ever a great sin."

\section{Banking Financing for Malaysian SMEs}

Various studies have been conducted to understand SMEs' credit evaluations process and financing decision patterns, especially for conventional banking. Most of the previous studies related to credit conducted in Malaysia focus on key determinant factors considered by banks in approving credit applications. Based on the findings of previous studies conducted in Malaysia, the findings are quite similar to some extent. The studies revealed the key determinants in credit approval and creditworthiness for repayment. Characteristic of the business owner has been identified as one of the core criteria being evaluated by bank officers. Wasiuzzaman et al (2020) identified that owner's character is identified as owner's attitude towards repayment of financial obligations where lenders will evaluate borrowers' trustworthiness subjectively. Similarly, Zairani and Zainah (2013) suggested that lenders conduct a search on borrowers' track record on loan repayment history, indicating borrowers' attitude and commitment towards existing financing. Shu-Teng et al (2015), addressed that one of the key determinants in loan repayment performance is borrower's characters which the study defined character as borrower's education level. Mohamad et al (2018) suggested that Character is one of the important elements for Islamic banks. In another study conducted by Mohamad et al (2018), the study examined owner's character based on Akhlak (Islamic ethics) which translated into good conduct, morals and character of a person. These studies indicated how much attention given by lenders towards borrower's character in analysing creditworthiness and repayment capability.

Previous studies also identified availability of collateral plays a significant role in credit approval. Although collateral is a last resort for payment in the event of default, many lenders still consider availability of collateral crucial for granting credit facilities for SMEs as collateral works as credit enhancement. Haron et al (2013) argued that lack of assets for collateral, such as land and equipment, is one of the causes for failing loan applications for newly established businesses. However, the collateral requirement is less likely to be required for established businesses. This argument was supported by Zairani and Zaimah (2013) and Wasiuzzaman et al (2020) which also believe that collateral is required as part of an incentive to reduce moral hazard, or in other words, collateral is treated as a credit insurance where lenders may liquidate the collateral for settling the outstanding debt. Zairani and Zaimah (2013) conducted interviews on five Malaysian banks. They learned that collateral is crucial for loan approval, especially for micro-SMEs, although a good relationship has been established with lenders.

The applicants' proposed loan structure and terms also play a significant role for lenders to consider and grant banking facilities. Mohamad et al (2018) proposed that Islamic credit evaluation should be based on the financing structure through PACAMP model, an acronym for Purpose, Ability, Character, Amount, Margin, and Payment Terms. In the proposed PACAMP model, the purpose of the loan is the most crucial element where lenders would like to know why the applicants need the money. In the same proposed PACAMP model, the researchers proposed another three components related to the loan structure: Amount, Margin of Financing and Payment Terms, i.e. tenure of the financing. Shu-Teng et al (2015) highlighted that loan and loan tenure have an incredible influence on credit approval as lenders prefer to participate in a reasonable amount of exposure with an appropriate length 
of time. The same study suggests that larger loan amounts and shorter tenure positively impact repayment performance for government agencies and non-government agencies. The study also highlighted that of all the elements highlighted in the study, the amount of loan is the most crucial factor in repayment performance. This argument was supported by Roslan and Abd Karim (2009) which their study revealed that the key determinants of loan repayment performance for Agrobank's borrowers are the amount of loan and the repayment period itself. Generally, most of the previous studies suggested that the proposed loan structure is the fundamental consideration for approving banking credit facilities.

It is no doubt that financial performance of the applicants is also important in lenders' decision-making process for granting credit exposure. The financial standing of the applicant simply indicates applicants' ability to repay the financial commitment in the future. A surveybased research that was distributed to 145 SMEs in Selangor and Kuala Lumpur conducted by Wasiuzzaman and Nurdin (2019) revealed that SMEs' financial performance plays a significant positive function in seeking debt financing. This argument was also supported by Zairani and Zaimah (2013) who have identified nine key determinants for credit approval which one of them is financial performance. The same study defined further financial performance as financial statement with prudent cashflow. In order to establish a healthy financial performance, businesses require a skilled and experience finance team that can produce a reasonable and detailed financial projection. Salikin et al (2013) supported that a company's capital strength is important for SMEs and a competent and skilled finance team will help strengthen this element in applying for external funding.

The tremendous research conducted in Malaysia has stressed strong linkage between good banking relationships and credit approval. Mohamad et al (2018) highlighted that bad banking relationships contribute to the failure of credit risk management in credit evaluation. The same study suggested that Ukhuwah (continuous relationship) is a crucial Islamic element in evaluating financing application as a healthy banking relationship leads to a healthy collaboration between lenders and clients, which leads to a better risk management approach due to transparency. A strong relationship with clients helps develop a deeper understanding of clients' credit-standing and character, which are fundamental considerations for loan approval (Haron et al., 2013).

Obviously, business characters have also been highlighted as a crucial consideration for loan approval. Business characteristic encompasses of nature of business, business model, industry, business plan and even track record of the respective company. Shu-Teng et al. (2015) claimed that creditworthiness can be ascertained through business experience in the respective field due to established clientele, which causes a stable revenue stream. Besides track record and established clientele, it is also important for SMEs to prove that they are engaging in viable business within a viable industry and supported by a prudent business plan that indicates a clear direction for the future. (Zairani and Zaimah, 2013). Roslan and Abd Karim (2009) also supported this argument, who believed that type of business would influence applicants' repayment ability as each business or project carries a different level of risk. Therefore repayment ability is affected by the business nature.

It is also important to understand that availability of sufficient information is important for credit evaluation, especially for SMEs where information typically is not well recorded. Mohamad et al (2018); Zairani and Zaimah (2013) highlighted the importance of information 
availability. Some applicants purposely hide crucial information such as business profile, management profile and cash flow. The study conducted on five banks revealed that it is essential for SMEs to submit complete documents to banks for credit processing. Lack of information will lead to a failure of risk management as the underlying risks are not being adequately addressed and mitigated accordingly.

Based on the findings of previous studies conducted in Malaysia, the findings are quite similar to some extent, where the key determinants for credit approval and repayment performance are similar. Lenders in Malaysia evaluate the character of the business owner in ascertaining their commitment towards financial obligations. Availability of collateral is also crucial for SMEs as exposure mitigation and exit mechanism. Loan structure such as tenure and purpose must also match with the financing requirement. Otherwise, it will affect repayment performance. The financial performance also important in ensuring SMEs' cash flow is sufficient to meet existing and newly proposed financial obligations. A banking relationship is also important, but the relationship alone is not enough for SMEs to obtain banking facilities. For both business characteristics and availability of information, sufficient and factual information must be furnished to lenders to process credit applications and mitigate risks.

\section{The Contribution of Research: Maqasid Shariah in Credit Evaluation Perspective}

This conceptual paper attempts to contribute in the area of credit evaluation as part of financing decision for SMEs application, especially for Islamic banks. This contribution is deemed unique and novel due to lack of previous studies focused on Maqasid Shariah values in evaluating SMEs credit-standing. Conventionally, financing decisions have been made based on the financial perspective alone, therefore, this research suggests that Maqasid Shariah may also be considered as part of financing decision makng process. Maqasid Shariah concept is considered as the biggest paradigm given that the theory was meant to cover the whole creations in the world, therefore Maqasid Shariah shall be the universe of this framework which the concept encompasses the other models and theories. This concept is a broad model of way of life which compulsorily to be practiced by Muslim in every aspect of their life e.g. financial, management, social and health. As protecting human being and wealth are the elements in Maqasid Shariah, therefore bank's risk appetite and credit evaluation consideration should be considered as sub-segments of the bigger paradigm of Maqasid Shariah. In other words, subscription of Maqasid Shariah concept by the Islamic banks shall influent bank's risk appetite and credit evaluation for SMEs' financing application.

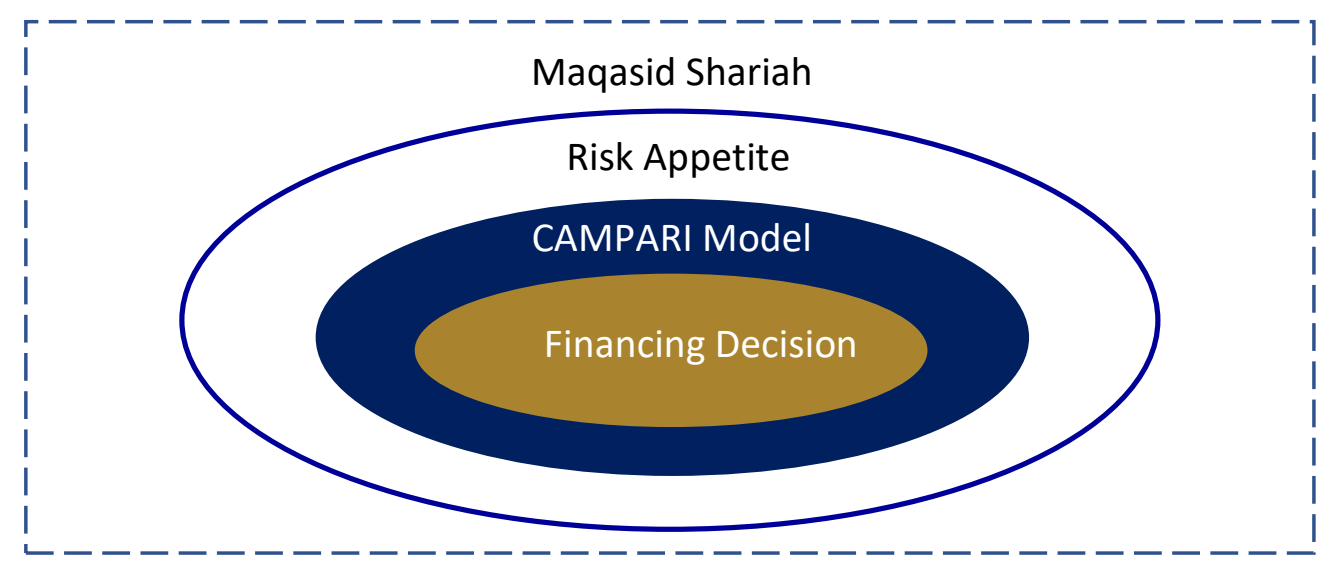

Figure 1: Conceptual Framework 
Secondly, bank's risk appetite is a concept practiced by Islamic banks in determining their willingness and affordability to expose to certain level of risk. For example, an Islamic bank is willing to finance projects managed by companies that aged not less than 3 years, as part of their mitigation strategies for risk of non-completion. In this case, company's age is the risk appetite for the bank for project-based financing. Each bank has its own unique risk appetite which driven by many reasons such as their past experience, size of capital and industry outlook assumption. Risk appetite is a smaller component of Maqasid Shariah because it is a part of Islamic rulings' universe', however it is a wider than credit evaluation (in this case CAMPARI) because Risk Appetite functions as Gate Keeper as it is typically stipulated in the credit policy.

Thirdly, credit evaluation or CAMPARI Model is the detailed assessment to be done on SMEs' financing application before the financing decision is being made. Based on CAMPARI, the credit appraiser should consider these 7 elements by taking consideration of Maqasid Shariah and risk appetite of the respective Islamic bank, for credit proposal submission for approval. The key contribution of the research is an unique framework which embeds CAMPARI with Maqasid Shariah values that can bring a new perspective in credit evaluation. The said framework on how Islamic banks may assess CAMPARI elements based on Islamic value, as following:

i. Character: Assessment on the applicant character should be done not only through faceto-face interview or checking report on repayment history, but also in the aspect of Amanah (Trustworthiness). Trustworthiness can also be assessed through interviews with applicant's customers or vendors to ascertain the applicant's trustworthiness in meeting financial obligations in the past.

ii. Ability to Pay: Customer's ability to pay is the most crucial elements in credit evaluation as it determines the level of risk. Transparency in business transaction is one of the crucial Islamic values. Therefore, source of repayment and ability for repayment need to transparent and well informed. The applicants need to present their cashflow projection to the bank in order to ascertain the level of potential risk. In promoting transparency in the applicant's ability to pay, the bank may partner up with independent professional consultant in validating the figures given in the cashflow projection and to confirm that the project will have sufficient cashflow to meet financial obligation in the future. Furthermore, the independent professional consultation may also assist the applicant in rationalizing their projection and turn it into more commercially feasible project. Addition to transparency, the bank must ensure that the applicants, including individual shareholders, are not a Muflis (bankrupt), which means have a sound legal and financial capacity to repay.

iii. Margin of Financing: Applicant's commitment toward a project or business is being assessed though margin of financing, the more capital injected by the applicant, the more committed the applicant is. However, applicant's commitment should not only rely on the margin of financing, but also level of Istiqamah (steadfastness) in committing to the business or project. One of the practical methods in monitoring customer's Istiqamah towards the business or projects is by requesting periodic operational and financial report to the bank. This report shall displays customer continuous commitment towards the business or project.

iv. Purpose of Financing: Similar to existing practice of Islamic banking, the purpose of the financing must be for Shariah compliant businesses. The business should not involve in 
usury-based activities, non-Shariah entertainments, Maysir (gambling), or involve nonhalal ingredients such as liquor, wine, beer or pork. Shariah non-compliant and Haram (prohibited) businesses are againts the key element of Maqasid Shariah which is protection of Deen (religion). Ascertaining the nature of business is not difficult as tpically Islamic banks would conduct Shariah screening as part of assessment process. Beside the nature of business, purpose of financing includes financing reasons such as operating expenditure financing, capital expenditure financing and refinancing. The bank needs to understand the actual requirement of financing, either for operating expenditure or capital expenditure, in which failure doing so may lead to financial burden in the future which is against one of the Maqasid Shariah elements i.e. protection of wealth.

v. Amount of Financing: It is very important to ascertain adequate financing amount as overfinancing will lead to higher gearing, while under-financing will cause performance failure. The approved financing amount should be adequate enough for the proposed project or business as under-financed project will jeopardize the wealth of the company or owner. Therefore, beside being capped by internal customer limit, the bank should also consider the actual and critical financing requirement of the business in ensuring its future continuous and growth potential.

vi. Repayment Structure: The financing tenure and repayment structure directly affect cashflow of the business. Shorter tenure will cause tight cashflow at the beginning, while longer tenure will exposre the bank to default risk. The repayment structure should have element of Syura (consultation) in deciding the tenure and the repayment terms. With consultation between the bank and the customer, the repayment structure shall be more flexible towards the business and projected cashflow. For example, step-up repayment where little principal repayment at the beginning of the tenure and the principal repayment increases throughout the tenure until at the end of tenure. Step-up repayment structure will be granted by the bank to meet its business cashflow which is can only be accomplished via consulatiton between both parties.

vii. Insurance or Security: In terms of security, SMEs are well-known for its lack capacity in providing collateral to support its financing proposal. In embedding Maqasid Shariah in security arrangement, the demanded collateral should not be too burdening to the applicants, but in the same, the bank's risk position is protected. Additionally, the collaterized assetsshould be free from any Haram (Prohibitted) elements, for example, disco, church, or evenwine factory should not the pledged assets in Islamic financing.

Financing decision is the responsibility of the approving authorities based on the mandate given by the Board. The approving authorities is expected to make consider the credit proposal based on their best knowledge and the information supplied to them by the credit appraiser and risk management department. Although the proposal shall have taken Maqasid Shariah and Risk Appetite into consideration, being the approving authorities, they may choose to accept or reject or differ the proposal. Being approving authorities for Islamic banks, their decisions are expected to be congruent with Maqasid Shariah and at the same time not to jeopardize bank's position by observing respective risk appetite. Therefore, having a framework for credit evaluation with embedded Maqasid Shariah values shall help the approving authorities in making financing decisions. 


\section{Conclusion and Future Research}

SMEs experience challenges at securing financing for their business requirements: for capital expenditure or operating expenditure, which resulting SMEs to utilize personal loan and credit card facility to fund their business. A research reveals that $46 \%$ of SMEs in the UK and the US capitalize their personal credit card to fund their businesses. This situation might due to various reasons; being one of them is poor understanding on the key determinants in credit evaluation for financing approval. It is no doubt that credit evaluation tools play significant role in financing decision where analysts are heavily depending on the given elements to analyse credit-standing of SMEs. However, a study needs to be conducted on how lenders behave towards SMEs' financing application in the lenses of CAMPARI Model. Future studies shall focus on Islamic banking, also known as Shariah banking, which supposedly to evaluate financing approval beyond merely profitability consideration, while upholding Islamic values. Islamic banking implies the 5 pillars of Maqasid Shariah which encompasses of religion, life, lineage, intellect and property. Therefore Islamic banks should evaluate the financing applications of SMEs as uniquely different than the counterparts of conventional banks. This study will also explore how the risk appetite in the Islamic banking influences credit evaluation for the SMEs.

Future studies on Shariah elements in credit evaluation will elevate the understanding on the key determinants and credit evaluation considerations for SMEs' financing, in which it will give significant benefits to various parties especially for SMEs and Islamic banks. For the SMEs, the ability to secure financing will help the business to grow; the cash conversion cycle improves and subsequently bridge the credit terms. For the Islamic banks, this study will offer them of valuable inputs; re-visiting of their credit evaluation process and taking the competitive advantages of Maqasid Shariah into kind consideration.

\section{References}

Abbadi, S. M., \& Karsh S. M. (2013) 'Methods of Evaluating Credit Risk used by Commercial Banks in Palestine', International Research Journal of Finance and Economics, 111 (July), pp. 146-159.

Association of Banks in Malaysia. (n.d.) 'Association of Banks in Malaysia'. Available at: https://www.abm.org.my/ (Accessed: 22 March 2020).

Baiden, J. (2011) 'The 5C's of Credit in the Lending Industry', Available at: Available at: http://ssrn.com/abstract=1872804.

Bhatt, N. (2012) 'Financing of SMEs and Credit Risk: The Inevitable 5Cs', Journal of Commerce and Trade, VII (1), pp. 13-17.

Boru, A. M. (2003) 'An Analysis of the Usefulness of Annual Financial Statements to Credit Risk Analysts in Kenyan Commercial Banks', University of Nairobi. Available at: http://erepository.uonbi.ac.ke/handle/11295/97025

Brown, K., \& Moles, P. (2014) 'Credit Risk Management', Great Britain. Edinburgh Business School.

Dusuki, A. W., \& Abozaid, A. (2007) 'A Critical Appraisal on the Challenges of Realizing Maqasid Al-Shariah in Islamic Banking and Finance', IIUM Journal of Economics and Management, 15 (2), pp. 143-165.

Haron, H., Said, S., Jayaraman, K., \& Ismail, I. (2013) 'Factors Influencing Small Medium Enterprises (SMEs) in Obtaining Loan', International Journal of Business and Social Science, 4(15), pp. 182-195. 
Hassan, A. A. (2020) 'Small and Medium Enterprise (SME) Financing: Credit Evaluation Method', FBM Insights, Volume 2, pp. 1-3

Jamil, I. K., Zakaria, R. H., \& Othman, A. (2019) 'An Evaluation of Financing Without Collateral to Small and Medium Enterprises in Malaysia: A Conceptual Framework', Academic Journal of Business and Social Sciences, Available at: http://202.58.91.156/index.php/ajobss/article/view/17.

Kithinji, A. M. (2010) 'Credit Risk Management and Profitability of Commercial Banks in Kenya', University of Nairobi. Available at:

http://erepository.uonbi.ac.ke/bitstream/handle/11295/40437/aibuma2011submission232.pdf?.

Metzler, M. G. (2014) 'Commercial Loans: Pay Attention to the 7 C's', Kreischer Miller. Available at: https://www.kmco.com/resource-center/article/leading-edge/commercialloans-pay-attention-to-the-7-cs/.

Mohamad, S. N., Basah, M. Y., \& Aziz, M. R. (2018) 'Implementation of Islamic Elements as a Parameter for Credit Evaluation Process: Exploring Shariah Adviser's Perceptions', International Journal of Academic Research in Business and Social Sciences, 8(6), pp. 745763.

Moti, H. O., Masinde, J. S., Mugenda, N. G., \& Sindani, M. N. (2012) 'Effectiveness of Credit Management System on Loan Performance: Empirical Evidence from Micro Finance Sector in Kenya', International Journal of Business, Humanities and Technology, 2(6), pp. 99-108.

Mustafa, R., Sam, M. F., \& Ismail, A. F. (2019) 'The Factors Financial Institutions Rejected Malaysian SMEs Loan Application', Journal of Environmental Treatment Techniques, 8(1), pp. 202-206.

Oladapo, I. A., \& Ab Rahman, A. (2016) 'Maqasid Shari'ah: The Drive for an Inclusive Human Development Policy', Jurnal Syariah, 24(2), pp. 287-302.

Pham, H. D. (2017) 'Determinants of New Small and Medium Enterprises (SMEs) Access to Bank Credit: Case Study in the Phu Tho Province, Vietnam', International Journal of Business and Management, 12(7), pp 83-99.

Roslan, A. H., \& Karim M. Z. (2009) 'Determinants of Microcredit Repayment in Malaysia: The Case of Agrobank', Humanity \& Social Sciences Journal, 4 (1), pp. 45-52.

Salikin, N., Wahab, N. A., \& Muhammad, I. (2013) 'Strengths and Weaknesses among Malaysian SMEs: Financial Management Perspectives', Procedia - Social and Behavioral Sciences, 129 (2014), pp. 334-340.

Shu-Teng, L., Hanim, M. S., \& Annuar, M. N. (2015) 'Determinants of Microfinance Repayment Performance: Evidence from Small Medium Enterprises in Malaysia', International Journal of Economics and Finance; 7(11), pp. 110-120.

Siswanto, H. P., Arifin, A. Z., \& Cavin (2019) 'Critical Factors that Determine Credit Approval to Micro, Small, and Medium Enterprises', E-Journal Universitas Islam Negeri Syarif Hidayatullah Jakarta, 18(1), pp 93-104. Available at: http://journal.uinjkt.ac.id/index. php/etikonomi/article/view/6722.

Talaulikar, H. S., \& Desai, P. H. (2015) 'Lending to Micro Small and Medium Enterprises: An Analysis of Bank Approaches and Risk Perceptions', The International Journal of Business \& Management, 3(6), pp. 77-83.

W/Mariam, G. S. (2017) 'The Application of CAMPARI Model in Lending Decision in the Case of Ethiopian Private Banks', Available at: http://www.repository.smuc.edu.et /handle/123456789/3163. 
Wasiuzzaman, S., Nurdin, N., Abdullah, A. H., \& Vinayan, G. (2020) 'Creditworthiness and Access to Finance: A Study of SMEs in the Malaysian Manufacutring Industry', Management Research Review, 43(3), pp. 293-310. DOI: 10.1108/MRR-05-2019-0221.

Wasiuzzaman, S., \& Nurdin, N. (2019) 'Debt financing decisions of SMEs in emerging markets: empirical evidence from Malaysia', International Journal of Bank Marketing, 37(1), pp. 258-277.

Yoshino, N., \& Taghizadeh-Hesary, F. (2016) 'Major Challenges Facing Small and Medium-sized Enterprises in Asia and Solutions for Mitigating Them', ADBI Working Paper Series, 564.

Zairani, Z., \& Zaimah, Z. A. (2013) 'Difficulties in Securing Funding from Banks: Success Factors for Small and Medium Enterprises (SMEs)', Journal of Advanced Management Science, 1(4), pp. 354-357. DOI: 10.12720/joams.1.4.354-357. 